\title{
FACTORS ASSOCIATED WITH THE QUALITY OF LIFE OF PATIENTS UNDERGOING HEMODIALYSIS
}

\author{
Gabriela Dutra Gesualdo ${ }^{1}$ Ana Laura Costa Menezes², Suzana Gabriela Rusa3a, Anamaria Alves Napoleão", \\ Rosely Moralez de Figueiredo, Vivian Ramos Melhado ${ }^{6}$, Fabiana de Souza Orlandi ${ }^{7}$
}

${ }^{1}$ Doctoral student in Sciences, Graduate Program in Fundamental Nursing, Escola de Enfermagem de Ribeirão Preto da Universidade de São Paulo. Ribeirão Preto, São Paulo, Brazil. E-mail: gabrielagesualdo@usp.br

${ }^{2}$ Doctoral student in Sciences, Graduate Program in Nursing at the Federal University of São Carlos (UFSCar). São Carlos, São Paulo, Brazil. E-mail: analauracmenezes@gmail.com

${ }^{3}$ B.A. in Gerontology. São Carlos, São Paulo, Brazil. E-mail: suzana.rusa@gmail.com

${ }^{4}$ Ph.D. in Nursing. Professor, Undergraduate Nursing Program, UFSCar. São Carlos, São Paulo, Brazil. E-mail: anamaria@ufscar.br

${ }^{5}$ Ph.D. in Nursing. Professor, Undergraduate Nursing Program, UFSCar. São Carlos, São Paulo, Brazil. E-mail: rosely@ufscar.br

${ }^{6}$ Ph.D. in Psychiatric Nursing. Professor, Undergraduate Program in Gerontology, UFSCar. São Carlos, São Paulo, Brazil. E-mail: vivianmelhado@ufscar.br

7 Ph.D. in Sciences. Professor, Undergraduate Program in Gerontology, UFSCar. São Carlos, São Paulo, Brazil. E-mail: fabi_ferreira@ yahoo.com.br

\section{ABSTRACT \\ Objective: to identify factors associated with the quality of life/spirituality, religion and personal beliefs of patients with chronic kidney disease undergoing hemodialysis. \\ Method: correlational cross-sectional study. The following instruments were applied through individual interviews: the WHOQOL-Bref, the WHOQOL-SRPB, along with a questionnaire to characterize the participants. The sample consisted of 110 participants with chronic kidney disease undergoing hemodialysis. Descriptive analysis was performed along with univariate and multiple logistic regression to identify associated factors. \\ Results: low level of albumin was mainly associated with the "physical" and "social relationships" domains of the WHOQOL-BREF. Participants without an occupation presented the greatest compromise in the domains "Connectedness to a spiritual being or force" and "Awe". In the domain "spiritual strength", participants worth an occupation presented higher chances of low quality of life. \\ Conclusion: the factors associated with the domains of quality of life of patients with chronic kidney disease undergoing hemodialysis were: occupation, marital status, sex, education, religion, levels of hematocrit and albumin, and overall health. \\ DESCRIPTORS: Quality of life. Renal insufficiency, Chronic. Renal dialysis. Patients. Spirituality. \\ FATORES ASSOCIADOS À QUALIDADE DE VIDA DE PACIENTES EM HEMODIÁLISE}

\section{RESUMO}

Objetivo: identificar fatores associados à qualidade de vida/espiritualidade, religião e crenças pessoais de pacientes que apresentam doença renal crônica e estão em hemodiálise.

Método: trata-se de estudo correlacional, de corte transversal. Realizou-se entrevista individual, com aplicação dos instrumentos WHOQOL-bref, WHOQOL-SRPB e instrumento de caracterização. A amostra foi composta por 110 participantes com doença renal crônica em hemodiálise. Foi realizada análise descritiva e de regressão logística univariada e múltipla, sendo esta última para identificação dos fatores associados.

Resultados: o valor inferior da albumina foi associado, especificamente, aos domínios "físico" e "relações sociais" do WHOQOL-bref. Participantes sem ocupação possuíam maior comprometimento no domínio "conexão a um ser ou força espiritual" e "admiração". No domínio "força espiritual", os participantes sem ocupação apresentaram maiores chances de baixa qualidade de vida.

Conclusão: os fatores associados aos domínios da qualidade de vida dos pacientes renais crônicos em hemodiálise foram: ocupação, situação conjugal, sexo, escolaridade, religião, hematócrito, albumina e estado geral de saúde.

DESCRITORES: Qualidade de vida. Insuficiência renal crônica. Diálise renal. Pacientes. Espiritualidade. 


\section{LOS FACTORES ASOCIADOS CON LA CALIDAD DE VIDA DE LOS PACIENTES EN HEMODIÁLISIS}

\section{RESUMEN}

Objetivo: identificar los factores asociados a la calidad de vida/espiritualidad, la religión y las creencias personales de los pacientes con enfermedad renal crónica en hemodiálisis.

Método: se trata de un estudio correlacional de corte transversal. Hemos llevado a cabo entrevistas individuales con la aplicación de los instrumentos: WHOQOL-BREF, WHOQOL-SRPB y instrumentos de caracterización. La muestra consistió en 110 participantes con enfermedad renal crónica en hemodiálisis. Se realizó un análisis descriptivo y logística variada y múltiple, este último para identificar los factores asociados.

Resultados: el valor más bajo de albúmina se asocia, sobre todo en los dominios "física" y "relaciones sociales" WHOQOL-BREF. Los participantes sin ocupación tenían un mayor déficit en lo dominio de "conexión a um ser o fuerza espiritual." Los encuestados que tenían un mayor déficit en lo dominio "admiración" se declararon en paro. En "fuerza espiritual", los participantes desempleados tenían más probabilidades de reducir la calidad de vida.

Conclusion: los factores asociados a la calidad de vida en pacientes con insuficiencia renal crónica en hemodiálisis fueron: ocupación, estado civil, sexo, educación, religión, hematocrito, albúmina y la salud general.

DESCRIPTORES: Calidad de vida. Insuficiencia renal crónica. Diálisis renal. Pacientes. Espiritualidad.

\section{INTRODUCTION}

Chronic Kidney Disease (CKD) can be defined by a renal parenchymal injury (with normal kidney function) and/or by impaired renal function that persists for a period of three months or longer. ${ }^{1}$ CKD has gained increased attention from the international scientific community as a high prevalence of it has been reported in recent studies. ${ }^{2}$

In Brazil, a total of 100,397 individuals are estimated to be undergoing dialysis, $90.8 \%$ of which receive it through hemodialysis. Its incidence rate in 2013 was 170 patients/1,000,000 inhabitants, while most of these patients are concentrated in the southeast. ${ }^{3}$

The difficulty in handling the disease arises from the fact it is asymptomatic at onset, which hinders early diagnosis, and because of the complexity of changes that occur due to the progressive decrease in the glomerular filtration rate that occurs, which leads to comorbidities, complications, kidney functional failure, and increased early mortality. ${ }^{4}$

A conservative or dialysis treatment must be implemented as soon as CKD is diagnosed; otherwise, complications may lead to death. The most frequently used treatment, hemodialysis, is a life-long treatment or continues until the patient undergoes successful kidney transplantation. ${ }^{5}$

Hemodialysis may affect the biological, psychological, economic and social dimensions of patients, interfering in Quality of Life (QOL); patients with CKD tend to experience worse QOL, a characteristic already associated with the growing population of individuals with CKD. ${ }^{6-7}$

Even though renal replacement therapies promote the maintenance and prolongation of life, they do not cure the disease and even harm one's daily life and QOL in the long run. ${ }^{8}$

Patients undergoing hemodialysis face limitations in their daily lives and also experience many losses and biopsychosocial changes, such as the loss of health (at a physiological and biochemical level), anemia, loss of physical, cognitive and sexual capacity, loss of the capacity to work and to perform other tasks and functions, and dependency on medical treatment and renal therapy, in addition to physical changes and body image, and diet and fluid restrictions associated with the treatment. ${ }^{9}$

Therefore, those living with CKD must adapt not only to the disease and its treatment, but also to the physiological, psychosocial and spiritual problems arising from this process ${ }^{10}$ which are situations that directly impact patients' QOL.

Religion and spirituality can be considered ways to assign meaning to life, having hope and accepting unpleasant events such as a chronic disease. ${ }^{11}$ Once patients have their QOL so deeply changed, religion, spirituality and personal beliefs become important tools for coping with the disease.

Religion and spirituality are important for patients undergoing dialysis because they influence important aspects of one's QOL and coping skills. Studies have recently reported associations between greater religiosity/spirituality and improved mental health (greater wellbeing and lower prevalence of depression, drug abuse and suicide), improved QOL, better coping strategies, lower mortality rates, shorter hospitalization lengths, and even improved immunological function. ${ }^{12}$

The number of QOL measures has increased in recent years as QOL has become the object of interest in many fields of knowledge. Existing 
instruments intended to assess QOL include the WHOQOL-100 and its short version (the WHOQOL-bref), which were developed by the World Health Organization (WHO). ${ }^{13-17}$

When spiritual aspects, religion and personal beliefs were identified as being relevant when assessing QOL around the world, the WHO included in the WHOQOL a module to assess Spirituality, Religion and Personal Beliefs (the SRPB module) from a cross-cultural perspective ${ }^{18}$.

Given the preceding discussion, this study's aim was to identify factors associated with QOL, spirituality, religion, and personal beliefs of patients with CKD undergoing hemodialysis. Scientific studies more deeply assessing the QOL of patients with a view to improve the implementation of therapeutic interventions and effectively promote the QOL of this population are increasingly needed. ${ }^{8-9}$

\section{METHOD}

This correlational, cross-sectional study was conducted in a dialysis center in the interior of São Paulo, Brazil. This nephrology center currently provides care for 165 patients covered by the Brazilian public health system and by private health insurance companies. The population was composed of people 18 years old or older with a medical diagnosis of CKD and undergoing hemodialysis in the aforementioned service.

A statistician calculated the sample size considering the estimated mean of the QOL domains of the WHOQOL-SRPB, establishing the level of significance at $1 \%$ (alpha or type I error), and sample error at $10 \%, 7 \%$ and $5 \%$ of the SRPB global score mean $(\mathrm{d}=0.4, \mathrm{~d}=0.3$ and $\mathrm{d}=0.2)$. After considering the mean and standard deviation of the scores obtained in the QOL domains in the current sample and a sample error of $\mathrm{d}=0.2$, a minimum number of 110 participants was established for all the domains and the global score to be representative of the sample. A convenience sample was recruited through an individual invitation of the patients present in the study setting at different periods of the day until the pre-established sample size was obtained ( $\mathrm{n}=110$ participants).

Eligibility criteria were: being 18 years old or older; undergoing hemodialysis for at least three months; being able to understand verbal communication and communicate verbally. This last criterion was assessed through dialogues; that is, we verified whether the patients were able to understand verbal language and also communicate verbally. Patients who were undergoing peritoneal dialysis, or who presented severe stroke sequalae, or presented severely impaired eyesight and/or hearing impairment, were excluded from the sample.

The patients attending the aforementioned dialysis center were individually invited to participate in the study and those who consented received clarification regarding the study's objectives as well as its risks and benefits, and signed free and informed consent forms. Data were collected by Gerontology students previously trained by the senior author.

The instruments of data collection were individually applied to each participant in a private room on the center's premises. The study met the ethical recommendations concerning studies involving human subjects and was approved by the Committee of Ethics in Research at the Federal University of São Carlos (Brazil) (Report No. 165/2012 - CAAE: 0317.0.135.000-11).

Note that the instruments were applied prior to the hemodialysis session and, considering some patients' potential visual problems and/or low educational level, we opted to apply the instruments through an interview, from January to April 2013.

The following instruments were used to collect data: sociodemographic and clinical characterization Questionnaire, the WHOQOL-bref and QOL instrument - Spirituality, Religiosity, and Personal Beliefs Module (WHOQOL-SRPB). The Sociodemographic and Clinical Characterization Questionnaire was composed of questions concerning the patients' identification (name, age, sex), sociodemographic data (education, religion, marital status, occupation) and clinical data (hematocrits and albumin levels and duration of hemodialysis). Note that the results of laboratory tests were collected from the patients' files after their consent.

The WHOQOL-bref was developed by the WHOQOL Group in 1998 and validated in Brazil in 2000. ${ }^{13}$ It is a generic instrument composed of 26 questions: two address overall QOL and the remaining address each of the facets of the WHOQOL-100, the instrument of origin. It presents four domains: physical, psychological, social relationships, and environment. ${ }^{18}$

This instrument's domains address the following facets: physical domain, that is, addressing pain and discomfort, energy and fatigue, sleep and rest, mobility, activities of daily living, medication or treatment dependency; psychological domain that assesses positive feelings, thinking, learning, memory and concentration, self-esteem, body image and appearance, negative feelings, spirituality, 
religion, beliefs; the social relationships domain addresses personal relationships, (social) support, sexual activity; and the environment domain that includes physical safety and protection, home environment, financial resources, health and social care, both its availability and quality, opportunity to acquire new information and skills, participation and opportunities for recreation/leisure, risk environment, and transportation. ${ }^{18}$

The calculation of the scores obtained for the WHOQOL-bref domains was performed using the SPSS, by multiplying the mean of each of the domain's items by four, with the results then analyzed by assigning scores to each of the questions. These results can be transformed into a scale from 0 to 100 ; the higher the score, the better the QOL. ${ }^{18}$

The WHOQOL-SRPB is an instrument developed by the WHO to measure QOL in which the Spiritual, Religion and Personal Beliefs module, composed of four questions, was added to the WHOQOL-100 after the importance of religion, spirituality and personal beliefs were identified as aspects that influence the QOL of individuals. A multi-center pilot test including 15 facets and 105 items was applied, resulting in an instrument of 32 items distributed into eight facets (Connectedness to a spiritual being or force, Meaning of life, Awe, Wholeness and integration, Spiritual strength, Inner peace, Hope and optimism and Faith). ${ }^{19}$

In Brazil, the Portuguese version of the WHOQOL-SRPB was validated in 2011. The answers to the instruments are organized on a Likert scale from 1 to 5 , from the least representative to the most representative. ${ }^{20}$
Mean scores were achieved by totaling the scores of the four specific questions of each facet and then dividing it by four, which vary from 1 to 5 . The higher the score, the better the individual's QOL. ${ }^{20}$

Data were entered into a spreadsheet in the Excel program and then transferred to the Statistical Package for the Social Sciences (SPSS for Windows), version 22.0 for analysis. Mean and median were calculated along with dispersion measures (standard deviation, minimum and maximum values) for a descriptive analysis of data. Univariate and multivariate logistic regression (Stepwise criterion) was performed to verify factors related to the QOL, spirituality, religion and personal beliefs of adult and elderly patients with CKD using the WHOQOLbref and WHOQOL-SRPB. The level of significance established for the statistical tests was $5 \%$, that is, p-value $\leq 0.05$.

\section{RESULTS}

The study included 110 participants: 74 men and 36 women. In regard to marital status, 70 were in a stable relationship and 40 were not. Most were between 50 and 59 years old (29.09\%), had from 1 to 8 years of education (49.09\%) and $79.08 \%$ did not have a formal job (Table 1).

In regard to the level of religiosity reported by the participants, most identified themselves as "very" or "extremely" religious (66.28\%). Of the 110 participants, only 74 answered the question concerning increased frequency of attending religious practices after being diagnosed with CKD, most of which reported more intensified religious practices (56.75\%) (Table 1).

Table 1 - Description of the sociodemographic characteristics of patients with chronic kidney disease. São Carlos, SP, Brazil, 2013. (n=110)

\begin{tabular}{llrr}
\hline Variable & Distribution by category & n & \% \\
\hline & 31 to 39 & 16 & 14.54 \\
Age groups (years) & 40 to 49 & 18 & 16.36 \\
& 50 to 59 & 32 & 29.09 \\
& 60 to 69 & 27 & 24.55 \\
Education & 70 to 79 & 12 & 10.91 \\
& 80 years old or older & 5 & 4.55 \\
Occupation & Zero & 11 & 10.00 \\
& 1 to 8 years & 54 & 49.09 \\
& 9 years or more & 45 & 40.91 \\
& No formal job & 87 & 79.08 \\
& Formal job & 23 & 20.92
\end{tabular}




\begin{tabular}{llcc}
\hline Variable & Distribution by category & n & \% \\
\hline & Not religious/a little & 14 & 12.72 \\
Self-reported religiosity & Moderate & 23 & 20.91 \\
& Very/Extremely & 73 & 66.28 \\
Religious practice intensified after & Yes & 42 & 56.75 \\
Chronic kidney disease $(\mathrm{n}=74)$ & No & 32 & 43.24 \\
\hline
\end{tabular}

In regard to the participants' clinical variables, table 2 shows that the average duration of hemodialysis was $46.35( \pm 47.69)$ months, with a maximum of 240 months. In regard to the laboratory exams, the average levels of hematocrits and albumin were $32.59 \%( \pm 5.19)$ and $3.78 \mathrm{~g} / \mathrm{dl}( \pm 0.34)$, respectively.
Note that the average level of hematocrits was below normal parameters both for men and women, while the average level of albumin was within values considered to be a normal serum concentration of this protein among humans.

Table 2 - Description of the participants' clinical variables, duration of hemodialysis, and levels of hematocrits and albumin. São Carlos, SP, Brazil, 2013. (n=110)

\begin{tabular}{lcccc}
\hline Variable & $\mathbf{n}$ & Mean $(\mathbf{s d})^{*}$ & Median & $\begin{array}{c}\text { Variation } \\
\text { (minimum - maximum) }\end{array}$ \\
\hline Duration of hemodialysis (months) & 110 & $46.35( \pm 47.69)$ & 36 & $0.06-240$ \\
Hematocrits (\%) & $109 \dagger$ & $32.59( \pm 5.19)$ & 33.30 & $15.00-47.40$ \\
Albumin $(\mathrm{g} / \mathrm{dl})$ & $109 \dagger$ & $3.78( \pm 0.34)$ & 3.90 & $2.10-4.30$ \\
\hline
\end{tabular}

*standard deviation; tpatients with laboratorial exams reported on their files.

In regard to the analysis of factors associated with the QOL of patients with CKD undergoing hemodialysis, the "physical" and "social relationships" domains in the WHOQOL-bref revealed that the participants who were at a higher risk of presetting poor QOL were those with low levels of albumin. Each additional unit of albumin decreased the likelihood of worse QOL by $74.2 \%$ and $78.9 \%$ in the "physical" and "social relationships," respectively (Table 3).

Table 3 - Analysis of logistic regression of variables associated with the WHOQOL-bref domains. São Carlos, SP, Brazil, 2013. (n=110)

\begin{tabular}{lccccc}
\hline Domains & Variable selected & Categories & p-value & OR $^{*}$ & CI95\% OR† \\
\hline Physical & Albumin & Continuous variable & 0.044 & 0.258 & $0.069-0.967$ \\
Psychological & -- & -- & -- & -- & -- \\
Social relationships & Albumin & Continuous variable & 0.024 & 0.211 & $0.055-0.814$ \\
Environment & -- & -- & -- & -- & -- \\
\hline
\end{tabular}

* Odds Ratio for quality of life; †Confidence interval of $95 \%$.

In regard to the analysis of logistic regression of the variables associated with the domains of the WHOQOL-SRPB instrument, table 4 shows that the respondents at a higher risk of experiencing poor QOL, specifically in the domain "Connectedness to a spiritual being or force" reported "no occupation", for whom the risk is 4.1 times greater than for those "with an occupation"; the risk of poor QOL decreases by $9.1 \%$ for each unit less of hematocrit.
In regard to the domain "meaning of life", non-religious male participants with low levels of education and without a stable partner were at a greater risk of experiencing poor QOL when compared to other groups. Participants with "no partner" are 8.5 times more likely to experience poor QOL in this specific dimension, while men are 5.1 times more likely than women. Participants with low levels of education are 4.3 times more likely to 
experience poor QOL than those with higher educational levels, while such a risk increased by 3.3 times among individuals who reported no religious practices compared to religious individuals (Table 4).

The participants who reported "no occupation" were 4.4 times more likely to experience poor QOL in the dimension "Awe" than those who reported an occupation. The risk of worse QOL in the domain "wholeness and integration" was 2.7 times greater among individuals "with no partner" and 2.8 times greater among those without an occupation. The participants with no occupation were more than 2.8 times more likely to present poor QOL in the domain "spiritual strength" in comparison to individuals with an occupation (Table 4).

Table 4 shows that patients "without a partner" and who rated their health as "poor/bad" were, respectively, 4.2 and 10.2 times more likely to present poor QOL in the domain "inner peace" compared to those in a stable relationship and "good/ great" self-reported health. Respondents at a greater risk of experiencing poor QOL in the domain "hope and optimism" were those who rated their health as poor or bad, with a risk 11.8 times greater than among those with a good or great health.

Male participants were 4.8 times more likely to experience poor QOL in the domain "faith" in comparison to women. Considering the global dimension of the WHOQOL-SRPB, non-religious individuals with no occupation or no partner were more likely to experience poor QOL in comparison to their counterparts. That is, individuals with no occupation were 4.1 times more likely than those with an occupation; those with no partner were 2.7 times more likely than those with a partner; and non-religious individuals were 2.6 times more likely than religious individuals (Table 4).

Table 4 - Logistic regression analysis of the variables associated with the domains of the WHOQOL Spirituality, Religiousness and Personal Beliefs. São Carlos, SP, Brazil, 2013 (n=110)

\begin{tabular}{|c|c|c|c|c|c|}
\hline Domains & Selected variables & Categories & p-value & OR $^{*}$ & CI 95\% OR† \\
\hline \multirow{5}{*}{$\begin{array}{l}\text { Connectedness } \\
\text { to spiritual } \\
\text { being or force }\end{array}$} & \multirow{2}{*}{ Occupation } & Has an occupation (ref) $\ddagger$ & --- & 1.00 & --- \\
\hline & & No occupation & 0.001 & 4.07 & $1.72-9.61$ \\
\hline & \multirow{3}{*}{$\begin{array}{l}\text { Hematocrits } \\
\text { Marital status }\end{array}$} & Continuous variable & 0.038 & 0.915 & $0.842-0.995$ \\
\hline & & Has a partner (ref) $\ddagger$ & --- & 1.00 & --- \\
\hline & & No partner & $<0.001$ & 8.48 & $2.61-27.60$ \\
\hline & \multirow{2}{*}{ Sex } & Female (ref) $\ddagger$ & --- & 1.00 & --- \\
\hline & & Male & 0.022 & 5.11 & $1.26-20.72$ \\
\hline \multirow{4}{*}{ Meaning } & \multirow{2}{*}{ Education } & $\begin{array}{l}\text { Beyond incomplete primary } \\
\text { school (ref.) } \ddagger\end{array}$ & --- & 1.00 & --- \\
\hline & & $\begin{array}{c}\text { Up to incomplete primary } \\
\text { school }\end{array}$ & 0.017 & 4.27 & $1.30-14.02$ \\
\hline & \multirow{2}{*}{ Religion } & Religious (ref) $\ddagger$ & --- & 1.00 & --- \\
\hline & & Non-religious & 0.041 & 3.29 & $1.05-10.29$ \\
\hline \multirow{2}{*}{ Awe } & \multirow{2}{*}{ Occupation } & Has an occupation (ref)‡ & --- & 1.00 & --- \\
\hline & & No occupation & 0.001 & 4.38 & $1.77-10.84$ \\
\hline \multirow{4}{*}{$\begin{array}{l}\text { Wholeness and } \\
\text { integrality }\end{array}$} & \multirow{2}{*}{ Marital status } & Has a partner (ref) $\ddagger$ & --- & 1.00 & --- \\
\hline & & No partner & 0.023 & 2.69 & $1.15-6.27$ \\
\hline & \multirow{2}{*}{ Occupation } & Has an occupation (ref) $\ddagger$ & --- & 1.00 & --- \\
\hline & & No occupation & 0.030 & 2.80 & $1.10-7.10$ \\
\hline \multirow{4}{*}{$\begin{array}{l}\text { Spiritual } \\
\text { strength }\end{array}$} & \multirow{2}{*}{ Occupation } & Has an occupation (ref) $\ddagger$ & --- & 1.00 & --- \\
\hline & & No occupation & 0.021 & 2.76 & $1.17-6.49$ \\
\hline & \multirow{2}{*}{ Marital status } & Has a partner (ref)‡ & --- & 1.00 & --- \\
\hline & & No partner & 0.001 & 4.19 & $1.76-9.99$ \\
\hline
\end{tabular}




\begin{tabular}{|c|c|c|c|c|c|}
\hline Domains & Selected variables & Categories & p-value & $\mathrm{OR}^{*}$ & CI 95\% OR† \\
\hline \multirow{3}{*}{ Inner peace } & \multirow{3}{*}{ Overall state } & Good or great (ref) $\ddagger$ & --- & 1.00 & --- \\
\hline & & Fair & 0.466 & 1.39 & $0.57-3.37$ \\
\hline & & Poor or bad & 0.009 & 10.23 & $1.78-58.69$ \\
\hline \multirow{3}{*}{$\begin{array}{l}\text { Hope and } \\
\text { optimism }\end{array}$} & \multirow{3}{*}{ Overall state } & Good or great (ref) $\ddagger$ & --- & 1.00 & --- \\
\hline & & Fair & 0.449 & 1.36 & $0.62-3.00$ \\
\hline & & Poor or bad & 0.025 & 11.81 & $1.37-101.52$ \\
\hline \multirow{4}{*}{ Faith } & \multirow{2}{*}{ Sex } & Female (ref) $\ddagger$ & --- & 1.00 & --- \\
\hline & & Male & 0.002 & 4.83 & $1.80-13.01$ \\
\hline & \multirow{2}{*}{ Occupation } & Has an occupation (ref) $\ddagger$ & --- & 1.00 & --- \\
\hline & & No occupation & 0.002 & 4.05 & $1.68-9.76$ \\
\hline \multirow{4}{*}{ Overall } & \multirow{2}{*}{ Marital status } & Has a partner (ref)‡ & --- & 1.00 & --- \\
\hline & & No partner & 0.023 & 2.74 & $1.15-6.55$ \\
\hline & \multirow{2}{*}{ Religion } & Religious (ref) $\ddagger$ & --- & 1.00 & --- \\
\hline & & Non-religious & 0.036 & 2.62 & $1.06-6.44$ \\
\hline
\end{tabular}

*Odds Ratio for lower scores; †CI 95\% OR=confidence interval of 95\% for odds ratio. Stepwise criterion for selection of variables; $\ddagger$ ref.: $\ddagger$ level of reference.

\section{DISCUSSION}

The sociodemographic and clinical characteristics found in this study, such as the prevalence of men, having a stable partner, incomplete primary school, large number of individuals with informal jobs and religious beliefs, corroborate the results reported by Brazilian and international studies. ${ }^{21-24}$

In regard to clinical factors associated with the QOL of patients with CKD who are undergoing hemodialysis, in regard to the "physical" and "social relationships" domains of the WHOQOL-bref, participants with lower levels of albumin were at a greater risk of experiencing poor QOL. One study conducted in Spain assessing the nutritional state of patients attending a hemodialysis center based on albumin levels reports that this is considered to be a good marker of the nutritional state of patients with a diagnosis of CKD, as well as that low levels of this protein are associated with a greater risk of morbidities and mortality. ${ }^{25}$

In regard to sociodemographic factors, patients with no occupation were at a greater risk of experiencing poor QOL in the domain "Connectedness to a spiritual being or force," while non-religious male individuals with no partner and with a low level of education are at a greater risk of presenting poor QOL in the domain "meaning of life". Respondents with no occupation were also at a greater risk of poor QOL in the domains "Awe" and "spiritual strength". In the domain "Wholeness and integrality", the participants with no job or no partner were at a greater risk of presenting poor QOL. Patients with no partner or who considered their health to be "poor/bad" were at a greater risk of presenting poor QOL concerning the "Inner peace" domain. In the dimension "Hope and optimism", the respondents at a greater risk of poor QOL were those who rated their health to be poor or bad. Male participants were at a greater risk of poor QOL in the domain "Faith," while non-religious participants, with no occupation or a partner were at a greater risk of experiencing poor QOL in the global dimension.

The search for factors associated with the QOL of patients with CKD undergoing hemodialysis revealed only one study using the WHOQOL-SRPB in this same population, along with another study using the WHOQOL-bref. For this reason, studies with similar results, but addressing different populations, are presented.

The study, the objective of which was to identify factors associated with health-related QOL in elderly patients undergoing hemodialysis, reports that worse QOL concerning the physical dimensions was associated with older age, being a woman, two or more hospitalizations in the last year, and three or more self-reported chronic diseases. ${ }^{26}$

The study analyzing whether the QOL of active healthy elderly individuals would be influenced by one's functional state, sociodemographic characteristics or psychological parameters reports that those in a stable relationship and with an income lower than five times the minimum wage, had a 
worse perception of the social and environment domains. In this study, however, those with no partner and with no occupation were at a greater risk of experiencing poor QOL. This finding may be explained by the fact that most participants in this study were men and, in general, adult men have a greater need of having a loving relationship. ${ }^{27}$

In order to verify potential associations between the presence of a chronic disease and the importance assigned to (SRPB), we verified that the importance assigned to SRPB appears to be positively associated with the global domain, and the psychological, social relationship, environment domains and SRPB in the WHOQOL-100, when adjusted for age, depressive symptoms, and the presence of a chronic health problem. ${ }^{19}$

Considering that nursing care requires constant adaptation to meet the individual needs of patients undergoing hemodialysis and improve their QOL, one study assessed the QOL of patients with CKD undergoing hemodialysis, in Alto Sertão da Paraíba (Brazil), and also to identify the correlation between overall quality of life and the various domains of the WHOQOL-bref. The authors identified that, in general, the domain most frequently compromised among the participants was the physical domain, while the most preserved was the social domain, reflecting the QOL of patients with CKD. ${ }^{14}$

One study that measured the QOL of elderly individuals with osteoporosis living in rural areas and that also verified associated factors, reports that QOL concerned with the physical domain presented, as the main predictor of lower scores, a higher number of morbidities. In the psychological domain, lower scores were associated with a lack of education and a greater number of morbidities. The environment domain presented lower scores of QOL associated with not being a homeowner and a greater number of morbidities. ${ }^{28}$

A literature review addressing correlations among religiosity, spirituality and QOL verified that QOL was correlated with both spirituality and religiosity, especially in the face of adverse situations. ${ }^{29}$ In this context, it is worth noting there is a lack of studies conducted of the CKD population addressing the relationship between these aspects and highlighting that this study's findings contribute to expanding knowledge in the field. The review made it clear the importance of these phenomena for health practices, confirming the need to value such aspects and including them in the formal education of health care professionals, especially nursing professionals who directly provide such care. ${ }^{29}$
This study's limitation is its cross-sectional design, which hinders the identification of the temporal precedence of the factors under study, an aspect that undermines making any assumptions regarding cause and effect relationships.

\section{CONCLUSION}

Based on the objectives and results, we concluded that the sociodemographic, economic and clinical characteristics found in this study are in agreement with Brazilian and international publications addressing the population with CKD; that is, most respondents were male, had a stable partner, had incomplete primary education, and many individuals had an informal job and held religious beliefs.

In regard to the sociodemographic and clinical factors associated with the QOL of patients with CKD undergoing hemodialysis, which were assessed using the WHOQOL-bref and the WHOQOL$\mathrm{SRPB}$, we verified that being a non-religious man, not having an occupation or a partner, presenting a low level of education, having low levels of hematocrits and albumin, and having poor or bad self-perceived health were associated with a worse perception of QOL.

This study is very relevant because it can aid the staff responsible for providing hemodialysis perceive the need and importance of identifying the clinical and demographic factors associated with QOL, enabling these professionals to optimize this modality of treatment.

Given the previous discussion, we recommend that healthcare providers working in dialysis centers, especially the nursing staff, take into account the sociodemographic and clinical aspects that were associated with the QOL, spirituality, religion and personal beliefs of patients with CKD undergoing hemodialysis to increase the likelihood these individuals will improve their perceptions of QOL and the aspects related to it, to help them cope with their disease and treatment.

\section{REFERENCES}

1. Bastos MG, Bregman R, Kirsztajn GM. Chronic kidney diseases: common and harmful, but also preventable and treatable. Rev Assoc Med Bras. 2010 [cited 2016 Jan 15]; 56(2):248-53. Available from: http://www.scielo.br/scielo.php?script=sci_ arttext\&pid=S0104-42302010000200028

2. Bastos MG, Kirsztajn GM. Chronic kidney disease: importance of early diagnosis, immediate referral and structured interdisciplinary approach to improve 
outcomes in patients not yet on dialysis. J Bras Nefrol. [Internet] 2011 [cited 2016 Jan 15];33(1):93108. Available from: http://www.scielo.br/pdf/jbn/ v33n1/en_v33n1a13.pdf

3. Sesso RCC, Lopes AA, Thomé FS, Lugon JR, Watanabe Y, Santos DR, et al. Inquérito brasileiro de diálise crônica 2013. J Bras Nefrol. [Internet] 2014[cited 2016 Feb 15]; 36(4):476-81. Available from: http://www.scielo.br/ pdf/jbn/v36n4/0101-2800-jbn-36-04-0476.pdf

4. Mansur HN, Damasceno VO, Bastos MG. Prevalence of frailty in patients in chronic kidney disease on conservative treatment and on dialysis. J Bras Nefrol. [Internet] 2012[cited 2016 Mar 15]; 34(2):153-60. Available from: http://www.jbn.org. br/details/1462/en-US/ prevalence-of-frailty-inpatients-in-chronic-kidney-disease-on-conservativetreatment-and-on-dialysis

5. Madeiro AC, Machado PDLC, Bonfim IM, Braqueais AR, Lima FET. Adherence of chronic renal insufficiency patients to hemodialysis. Acta Paul Enferm. [Internet] 2010 [cited 2016 Jun 15]; 23(4):546-51. Available from: http:/ / www.scielo.br/scielo.php?pid=S010321002010000400016\&script $=$ sci_arttext\&tlng $=$ en

6. Abraham S, Venu A, Ramachandran A, Chandran PM, Raman S. Assessment of quality of life in patients on hemodialysis and the impact of counseling. Saudi J Kidney Dis Transpl. [Internet] 2012 [cited 2016 Jun 15]; 23(5):953-7. Available from: http://www.sjkdt. org/article. asp? issn=1319-2442; year $=2012$; volume $=$ 23; issue $=5$; spage $=953$; epage $=957$; aulast $=$ Abraham

7. Turkmen K, Yazici R, Solak Y, Guney I, Altintepe L, Yeksan $\mathrm{M}$, et al. Health-related quality of life, sleep quality and depression in peritoneal dialysis and hemodialysis patients. Hemodial Int. [Internet] 2012 [cited 2016 Jun 15];16(2):198-206. Available from: http:/ / onlinelibrary.wiley.com/doi/10.1111/j.15424758.2011.00648.x/epdf?r3_referer=wol\&tracking action=preview_click\&show_checkout $=1 \&$ purchase referrer $=w w w$.google.com.br\&purchase_site license=LICENSE_DENIED

8. Guerra-Guerrero V, Sanhueza-Alvarado O, CáceresEspina M. Quality of life in people with chronic hemodialysis: association with sociodemographic, medical-clinical and laboratory variables. Rev Latino-Am Enfermagem. [Internet] 2012 [cited 2016 Jun 15]; 20(5):838-46. Available from: http://www.scielo.br/scielo.php? script $=$ sci arttext\&pid=S0104-11692012000500004

9. Grasselli CSM, Chaves ECL, Simão TP, Botelho PB, Silva RR. Assessment of quality of life in patients undergoing hemodialysis. Rev Bras Clin Med. [Internet] 2012 [cited 2016 Jan 15]; 10(6):503-7. Available from: https://www.intechopen.com/ books/hemodialysis/quality-of-life-in-patientsundergoing-hemodialysis

10. Chaves ECL, Carvalho EC, Terra FS, Souza L. Clinical validation of impaired spirituality in patients with chronic renal disease. Rev Latino-Am Enfermagem.
[Internet] 2010 [cited 2016Jun15]; 18(3):309-16. Available from: http:/ / www.scielo.br/scielo.php?script=sci arttext\&pid=S0104-11692010000300003

11. Valcanti CC, Chaves ECL, Mesquita AC, Nogueira $\mathrm{D}$, Carvalho EC. Religious/spiritual coping in people with chronic kidney disease undergoing hemodialysis. Rev Esc Enferm USP. [Internet] 2012 [cited 2016 Jun 15]; 46(4):838-45. Available from: http://www. scielo.br $/$ scielo.php?script=sci_arttext\&pid=S008062342012000400008\&lng=en\&nrm=iso\&tlng=en

12. Lucchetti G, Almeida LGC, Granero AL. Spirituality for dialysis patients: should the nephrologist address? J Bras Nefrol. [Internet] 2010 [cited 2016 Jan 15]; 32(1):128-32. Available from: http://www. scielo.br/scielo.php?script=sci_arttext\&pid=S010128002010000100020\&lng=en\&nrm=iso\&tlng=en

13. Fleck MPA, Louzada S, Xavier M, Chachamovich E, Vieira G, Santos L, et al. Application of the Portuguese version of the abbreviated instrument of quality life WHOQOL-bref". Rev Saúde Pública. [Internet] 2000 [cited 2016 Jan 15]; 34(2):178-83. Available from: http:/ / www.scielo.br/scielo.php?script=sci_ arttext\&pid=S0034-89102000000200012

14. Costa GMA, Pinheiro MBGN, Medeiros SM, Costa $\mathrm{RRO}$, Cossi MS. Quality of life of patients with chronic kidney disease undergoing hemodialysis. Enferm Glob. [Internet] 2016 [cited 2016 Jul 31]; 15(43):5973. Available from: http://scielo.isciii.es/pdf/eg/ v15n43/en_clinica3.pdf

15. Rusa SG, Peripato GI, Pavarini SCI, Inouye K, Zazzetta MS, Orlandi FS Quality of life/spirituality, religion and personal beliefs of adult and elderly chronic kidney patients under hemodialysis. Rev Latino-Am Enfermagem. [Internet] 2014 [cited 2016 Jun 15]; 22(6):911-7. Available from: http://www.scielo.br/ pdf/rlae/v22n6/0104-1169-rlae-3595-2495.pdf

16. Santos VC, Boery EN, Pereira R, Rosa DOS, Vilela $\mathrm{ABA}$, Anjos KF et al. Socioeconomic and health conditions associated with Quality of life of elderly quilombolas. Texto Contexto Enferm. [Internet] 2016 [cited 2016 Jul 31]; 25(2):e1300015. Available from: http:/ / www.scielo.br/scielo.php? script=sci arttext\&pid=S0104-07072016000200303

17. Magalhães SR, Carvalho ZMF, Andrade LM, Pinheiro $\mathrm{AKB}$, Studart RMB. Influence of spirituality, religion and beliefs in the quality of life of people with spinal cord injury. Texto Contexto Enferm. [Internet] 2015 [cited 2016 Jun 15]; 24(3):792-800. Available from: http:/ / www.scielo.br/scielo.php? script $=$ sci $_{-}$ arttext\&pid=S0104-07072015000300792

18. Cruz LN, Polanczyk CA, Camey SA, Hoffmann JF, Fleck MP. Quality of life Brazil: normative values for the Whoqol-bref in a southern general population sample. Qual Life Res. 2011; 20:1123-29.

19. Rocha NS, Fleck MP. Evaluation of quality of life and importance given to spirituality/religiousness/ personal beliefs (SRPB) in adults with and without 
chronic health conditions. Rev Psiq Clín. [Internet] 2011 [cited 2016 Jun 15]; 38(1):19-23. Available from: http:/ / www.scielo.br/scielo.php?pid=S010160832011000100005\&script $=$ sci_arttext\&tlng $=$ en

20. Panzini RG, Maganha C, Rocha NS, Bandeira DR, Fleck MP. Brazilian validation of the Quality of Life Instrument/spirituality, religion and personal beliefs. Rev Saúde Públ. [Internet] 2011 [cited 2016 Jun 15]; 45(1):153-65. Available from: http:/ / www.scielo.br/scielo.php? script $=$ sci $_{-}$ arttext\&pid=S0034-89102011000100018

21. Orlandi FS, Gesualdo GD. Assessment of the frailty level of elderly people with chronic kidney disease undergoing hemodialysis. Acta Paul Enferm. [Internet] 2014; 27(1):29-34. Available from: http:/ / www.scielo.br/scielo.php?script=sci arttext\&pid=S0103-21002014000100007

22. Tennankore KK, Hingwala J, Watson D, Bargman JM, Chan CT. Attitudes and perceptions of nephrology nurses towards dialysis modality selection: a survey study. BMC Nephrol. [Internet] 2013 [cited 2016 Jun 15]; 14:192. Available from: http://bmcnephrol.biomedcentral.com/ articles/10.1186/1471-2369-14-192

23. Rognant N, Alamartine E, Aldigier JC, Combe C, Vendrely B, Deteix P et al. Impact of prior CKD management in a renal care network on early outcomes in incident dialysis patients: a prospective observational study. BMC Nephrol, [Internet] 2013 [cited 2016 Jun 15]; 14:41. Available from: http:/ / bmcnephrol.biomedcentral.com/ articles/10.1186/1471-2369-14-41

24. Thomé EGR, Meyer DEE. Women caregivers for men with chronic kidney disease: a cultural approach. Texto Contexto Enferm. [Internet] 2011 [cited 2016 Jun 15]; 20(3):503-11. Available from: http:// www.scielo.br/scielo.php?script=sci arttext\&pid=S0104-07072011000300011

25. Alfonso AIQ, Castillo RF, Gallegos RF, Jimenéz FJG. Estudio de la albúmina sérica y del índice de masa corporal como marcadores nutricionales en pacientes en hemodiálisis. Nutr Hosp. [Internet] 2015 [cited 2016 Jun 15]; 31(3):1317-22. Available from: http://www. aulamedica.es/gdcr/index.php/nh/article/view/8084

26. Braga SFM, Peixoto SV, Gomes IC, Acúrcio FA, Andrade EIG, Cherchiglia ML. Factors associated with health-related quality of life in elderly patients on hemodialysis. Rev Saúde Pública. [Internet] 2011 [cited 2016 Jun 15]; 45(6):1127-36. Available from: http:/ / www.scielo.br/scielo.php?pid=S0034$89102011000600015 \&$ script $=$ sci_arttext\&tlng=en

27. Alexandre TS, Cordeiro RC, Ramos LR. Factors associated to quality of life in active elderly. Rev. Saúde Públ. [Internet] 2009 [cited 2016 Jun 15]; 43(4):61321. Available from: http://www.scielo.br/scielo. php?script=sci_arttext\&pid=S0034-89102009000400007

28. Tavares DMS, Gomes NC, Dias FA, Santos NMF. Factors associated to the quality of life for elderly people with osteoporosis, living at rural areas. Esc Anna Nery. [Internet] 2012 [cited 2016 Jun 15]; 16(2):371-8. Available from: http:/ / www.scielo.br/scielo.php?script=sci arttext\&pid=S1414-81452012000200023

29. Melo CF, Sampaio IS, Souza DLA, Pinto NS. Correlation between religiousness, spirituality and quality of life: a review of literature. Estud Pesqui Psicol. [Internet] 2015 [cited 2016 Jun 15]; 15(2):44764. Available from: http://www.e-publicacoes.uerj. br/index.php/revispsi/article/view/17650/13050
Correspondence: Fabiana de Souza Orlandi

Universidade Federal de São Carlos - Departamento de Gerontologia

Rodovia Washington Luís, km 235 - SP-310

13565-905 - São Carlos, SP, Brasil

E-mail: forlandi@ufscar.br
Received: February 11,2016

Approved: October 20, 2016 